\title{
МОРФОЛОГИЧЕСКАЯ И ГЕНЕТИЧЕСКАЯ ИЗМЕНЧИВОСТЬ ЦЕНОПОПУЛЯЦИЙ ANEMONE JENISSEENSIS (RANUNCULACEAE) НА ЮГЕ ПРИЕНИСЕЙСКОЙ СИБИРИ
}

\author{
(C) 2020 г. А. Н. Мариничева ${ }^{1, *}$, И. Е. Ямских ${ }^{1}$, Н. В. Степанов ${ }^{1}$, М. Г. Куцев ${ }^{1,2}$ \\ ${ }^{1}$ Сибирский федеральный университет \\ пр. Свободный, 79, Красноярск, 660041, Россия \\ ${ }^{2}$ Алтайский государственный университет \\ ул. Ленина, 61, Барнаул, 656049, Россия \\ *e-mail: alexandra.marinicheva@outlook.com \\ Поступила в редакцию 01.11.2019 г. \\ После доработки 22.01.2020 г. \\ Принята к публикации 28.02.2020 г.
}

\begin{abstract}
Изучена морфологическая и генетическая изменчивость 10 природных ценопопуляций сибирского эндемика Anemone jenisseensis (Korsh.) Krylov, произрастающих в растительных сообществах Красноярской лесостепи, Западного и Восточного Саяна. Установлено, что данный вид обладает относительно широким фитоценотическим ареалом и может встречаться в мелколиственных (березовые, осиновые леса), светлохвойных (сосняки), смешанных лесах, в пойменных ивняках, а также на вы-

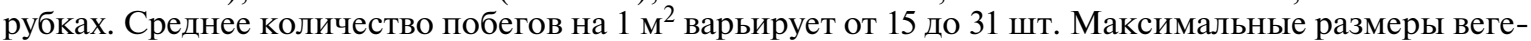
тативных органов, показатели семенной продуктивности и генетического разнообразия вида наблюдаются в подтаежных лесах Западного Саяна и в Красноярской лесостепи. На вырубках отмечается достоверное снижение морфологических показателей Anemone jenisseensis, однако уровень внутрипопуляционной модификационной изменчивости и показатели семенной продуктивности варьируют в пределах средних значений. Генетическую изменчивость ценопопуляций Anетопе jenisseensis выявляли с помощью ISSR-PCR (Inter Simple Sequence Repeats) метода. Суммарный процент полиморфных локусов составляет 100. Изученные ценопопуляции характеризуются средним уровнем внутрипопуляционного генетического разнообразия (55.86-71.17\%) и очень высокой степенью дифференциации $\left(\mathrm{G}_{\mathrm{st}}=0.3316\right)$. На дендрограммах сходства, построенных на основе морфологических и генетических данных, достоверно выделяется группа ценопопуляций, характеризующаяся крупными, глубоко расчлененными боковыми сегментами листа. Разделения ценопопуляций по географическому принципу не выявлено.
\end{abstract}

Ключевые слова: Anemone jenisseensis, эндемик, морфолого-генетический анализ, ценопопуляции, ISSR-PCR, генетическое разнообразие, Южная Сибирь, Красноярский край, Хакасия

DOI: $10.31857 / \mathrm{S} 0006813620040079$

Одной из наиболее интересных и относительно слабо изученных в Южной Сибири является группа весенних эфемероидов, принадлежащих к роду Anemone: Anemone reflexa Steph., A. jenisseensis (Korsh.) Krylov, A. altaica (C.A. Mey) Holub, Anemone caerulea DC. Данные виды относятся к числу эндемиков, третичных неморальных реликтов и занесены в сводки редких и исчезающих видов растений различного уровня.

Объектом нашего исследования является сибирский эндемик A. jenisseensis. Распространена в пределах Красноярского края, Хакасии. Встречается в лесах Томской, Кемеровской, Иркутской областей. Растение включено в “Красную книгу Иркутской области” (Red..., 2010) - категория 2 (V), уязвимый вид.
Для разработки методов сохранения генетического разнообразия редких видов необходимы сведения о полиморфизме и генетической структуре их ценопопуляций (Filippov, Andronova, 2017). Работы по изучению генетического разнообразия представителей рода Anemone проводились преимущественно за рубежом (Schuettpelz et al., 2002; Cai et al., 2009; Mlinarec et al., 2011; Sun et al., 2012; Zhang et al., 2015; Jiang et al., 2017), и, лишь в некоторых случаях, в Сибири (Marinicheva, Yamskikh, 2017; Yamskikh et al., 2011). Среди сибирских видов ветрениц менее всего изучена Anemone jenisseensis. В настоящее время отсутствуют сведения о морфологической и генетической структуре популяций, внутривидовой дифференциации данного вида. 


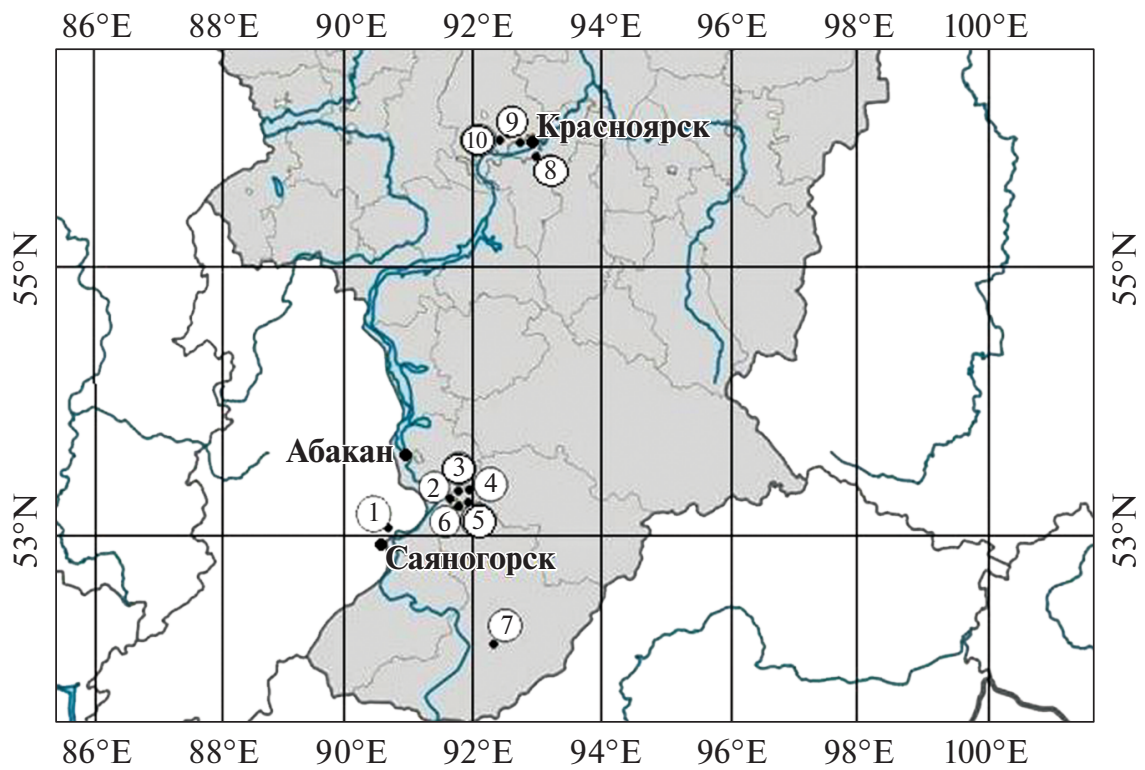

Рис. 1. Расположение ценопопуляций Anemone jenisseensis (нумерация в соответствии с табл. 1).

Fig. 1. Map of the location of Anemone jenisseensis coenopopulations (the numbers correespond to Table 1).

A. jenisseensis относится к семейству Ranunculaсеае и представляет собой многолетнее травянистое растение с членистым, распадающимся, мясистым корневищем (Luferov, Starodubtsev, 1995). B естественных условиях ветреница енисейская размножается, преимущественно, вегетативным способом, путем отмирания более старых участков корневищ и обособления самостоятельных особей (Barykina, 1995).

Цель исследования - изучение морфологогенетической изменчивости природных ценопопуляций (ЦП) A. jenisseensis.

\section{МАТЕРИАЛЫ И МЕТОДЫ}

Сбор материала проводился в период 20072018 гг. в Красноярской лесостепи, в горах Западного и Восточного Саяна (рис. 1). Объектом исследования явились 10 ценопопуляций A. jenisseensis. На первом этапе исследования изучали фитоценотическую приуроченность ветреницы. В исследуемом районе описано свыше 50 местообитаний вида. Геоботанические описания проведены по общепринятым методикам (Voronov, 1973). При изучении состояния ценопопуляций ветреницы енисейской определяли проективное покрытие, плотность, оценивали изменчивость вегетативных и генеративных признаков, семенную продуктивность, изучали генетическую вариабельность на основе ISSR-PCR анализа. Характеристика местообитаний вида приведена в табл. 1.

Измерения параметров вегетативных органов и показателей семенной продуктивности ветре- ницы для оценки фенотипической изменчивости проводили на 30 генеративных побегах. Большая часть оцениваемых нами морфометрических признаков приводится в качестве диагностических для определения видов во “Флоре СССР" (Yuzepchuk, 1937), “Флоре Средней Сибири” (Popov, 1957), “Флоре Сибири” (Timokhina, 1993). Кроме метрических, использовался и ряд аллометрических параметров, оценивающих соотношение в развитии разных частей растений. Показатели семенной продуктивности определяли по методике Г.П. Дюрягиной и М.М. Ивановой (Dyuryagina, Ivanova, 1985). У побегов ветреницы енисейской измерялись следующие параметры: длина стебля $(\times 1)$, длина цветоноса $(\times 2)$, длина черешка $(\times 3)$, длина $(\times 4)$ и ширина $(\times 5)$ центрального сегмента листа, соотношение длины и ширины листа $(\times 6)$, соотношение длины стебля и длины листа $(\times 7)$, глубина выреза на центральном сегменте $(\times 8)$, соотношение длины выреза и длины листа $(\times 9)$, количество зубчиков $(\times 10)$, длина $(\times 11)$ и ширина $(\times 12)$ бокового сегмента листа, количество зубчиков на боковом сегменте $(\times 13)$, длина выреза на боковом сегменте $(\times 14)$, соотношение длины выреза и длины листа $(\times 15)$, длина $(\times 16)$ и ширина $(\times 17)$ лепестков, количество цветков $(\times 18)$, реальная $(\mathrm{c} 1)$ и потенциальная $(\mathrm{c} 2)$ семенные продуктивности; коэффициент семенификации (c3).

При математической обработке данных рассчитывали пределы варьирования признака (minmax), среднее арифметическое $(X)$ и его ошибку $\left(m_{x}\right)$, среднее квадратичное отклонение $(\sigma)$, коэффициент вариации $(C v)$. Характер распределения 


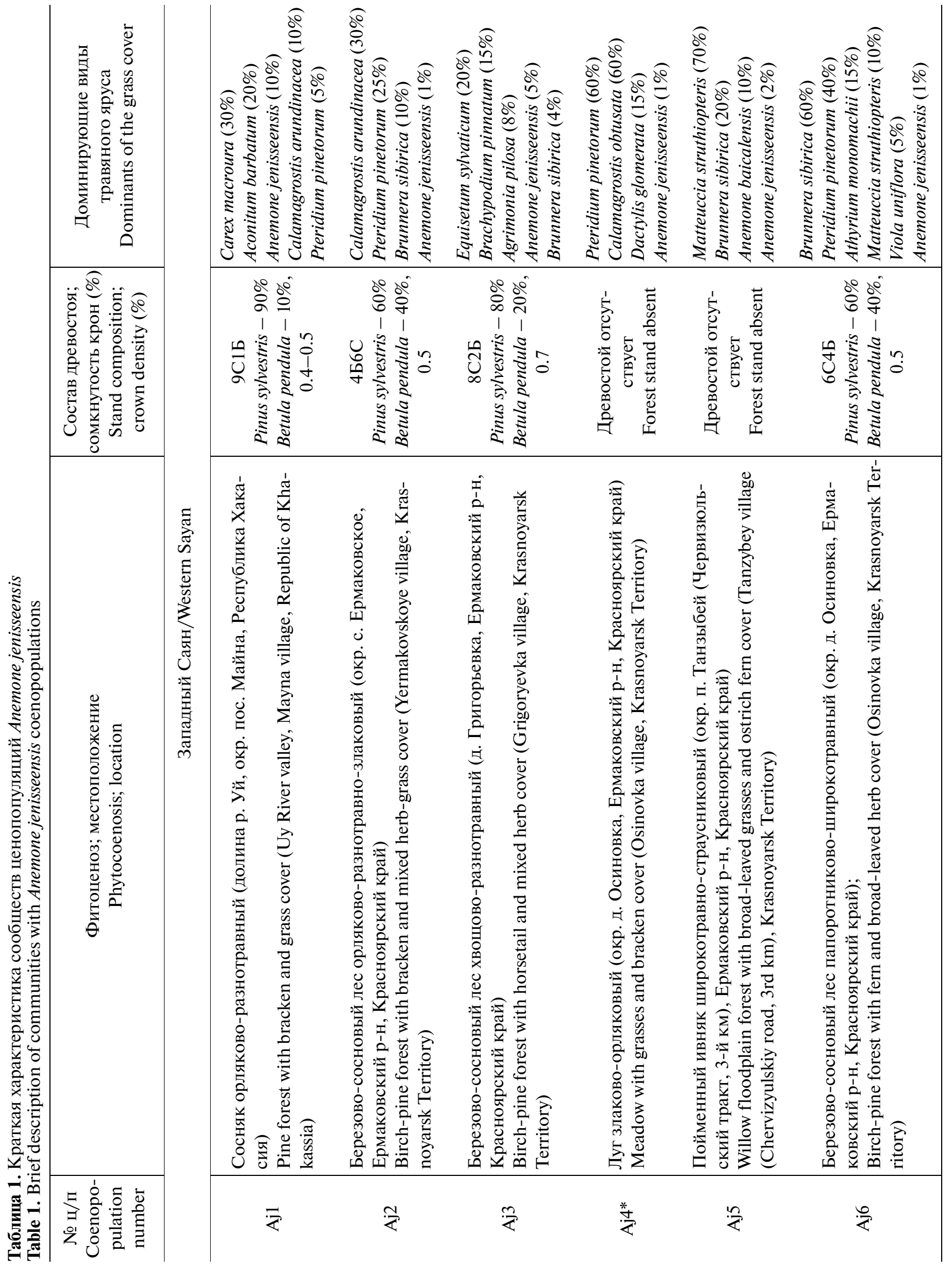




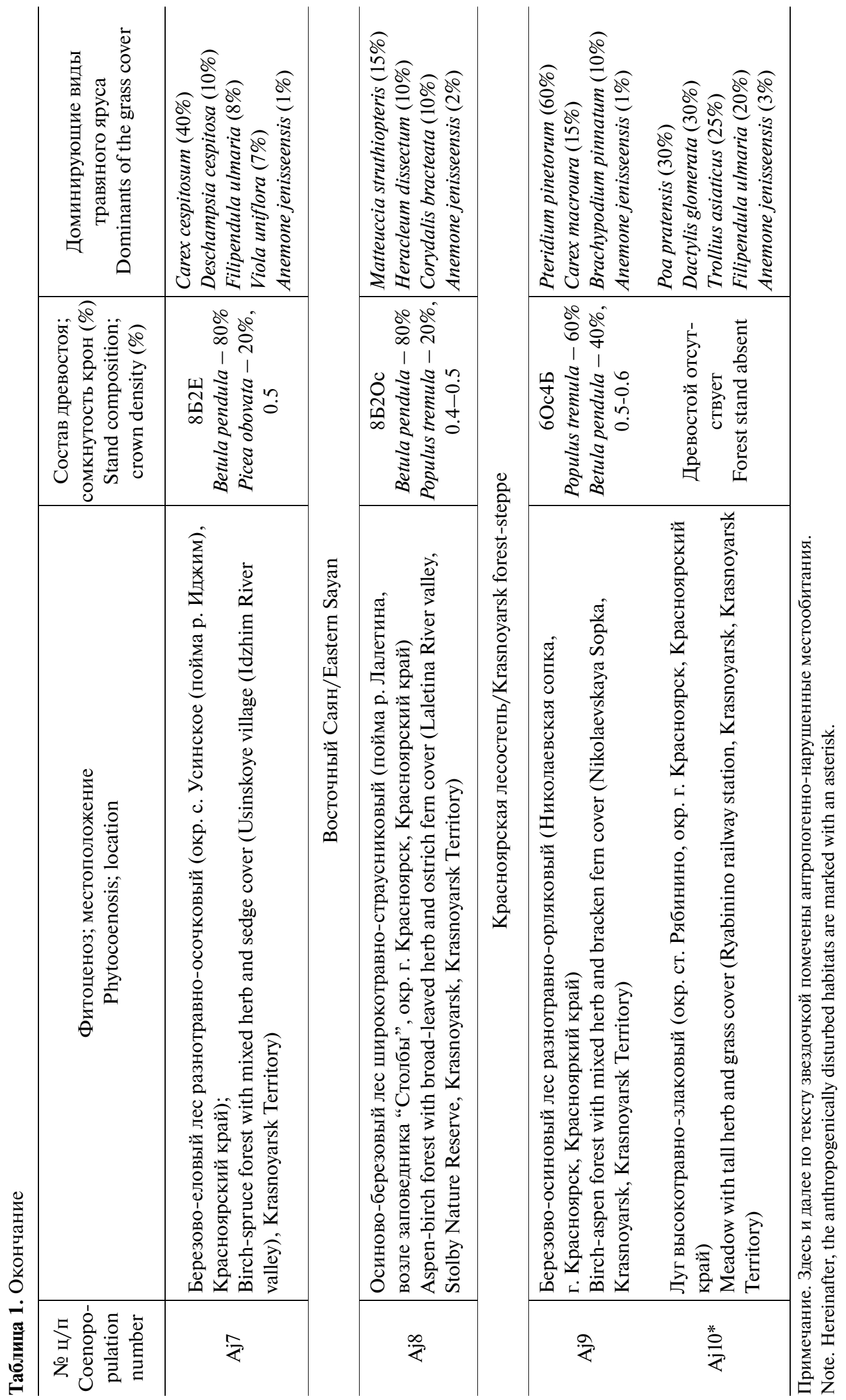


значений признаков ветреницы енисейской оценивали с помощью коэффициентов асимметрии и эксцесса. Выявлено, что для изучаемых нами параметров характерно распределение, близкое к нормальному. Внутрипопуляционную изменчивость признаков оценивали с помощью коэффициента вариации $(C v)$, поскольку данный параметр позволяет сравнивать признаки, имеющие различные размерности (Schmidt, 1984), кроме того, для коэффициента вариации С.А. Мамаевым (Mamaev, 1972) разработана шкала уровней изменчивости. Для установления достоверных различий между среднепопуляционными значениями одноименных признаков $A$. jenisseensis использовался однофакторный дисперсионный анализ. Различие считалось достоверным при уровне значимости $p<0.05$. Анализ сходства ценопопуляций по исследуемым признакам проводили с помощью кластерного анализа. В обработке применялся метод Уорда (Ward, 1963). В качестве меры сходства использовали Евклидово расстояние.

Генетическую вариабельность ценопопуляций вида изучали с помощью ISSR-PCR (Inter Simple Sequence Repeat) метода, выявляющего полиморфизм межмикросателлитных последовательностей ДНК. Из каждой популяции было проанализировано 10 растений, не являющихся клонами. Геномную ДНК выделяли из 10 мг материала, высушенного в силикагеле, с использованием набора DiamondDNA (OOO “АБТ”, Россия). Для ПЦР использовали смесь БиоМастерНS-Taq ПЦР-Color 2x(OOO “Биолабмикс", г. Новосибирск).

ISSR-PCR проводили в 20 мкл смеси (6 мкл $\mathrm{H}_{2} \mathrm{O} ; 10$ мкл смеси БиоМастер HS-Taq ПЦР-Color 2x, 2 мкл ДНК; 2 мкл 10 мМ праймера) на амплификаторе C1000 Thermal Cycler BioRad с использованием реактивов производства ООО "БиолабМикс" (г. Новосибирск) и ЗАО “Евроген” (г. Москва). Амплификацию проводили по следующей программе: $95^{\circ} \mathrm{C}-5$ мин; 13 циклов: $95^{\circ} \mathrm{C}-$ 20 сек, $55^{\circ} \mathrm{C}-45$ сек с последующим понижением температуры на $0.7^{\circ} \mathrm{C}$ в каждом цикле, $72^{\circ} \mathrm{C}-$ 90 сек; 25 циклов: $95^{\circ} \mathrm{C}-20$ сек, $44^{\circ} \mathrm{C}-30$ сек, $72^{\circ} \mathrm{C}-90$ сек; завершающая стадия: $72^{\circ} \mathrm{C}-10$ мин, охлаждение при $4^{\circ} \mathrm{C}$. Предварительно на 2 образцах ДНК из имеющегося набора праймеров (Mansour et al., 2009; Paterson et al., 2009) опытным путем были выявлены те, которые дают воспроизводимый полиморфный результат. Анализ продуктов амплификации осуществляли в проходящем ультрафиолетовом свете с помощью системы гель-документирования и анализа изображений Bio-Rad Gel Doc XR (Bio-Rad, USA).

Для количественной оценки степени полиморфизма и определения уровня дивергенции между изучаемыми популяциями полученные данные были представлены в виде матрицы бинарных признаков, в которой наличие или отсутствие ISSR-ПЦР фрагментов одинакового размера рассматривалось как состояние 1 или 0 соответственно. При этом учитывали только воспроизводимые в повторных экспериментах фрагменты. Обработку результатов анализа проводили с помощью пакета программ TFPGA version 1.3 (Miller, 1997) (UPGMA-анализ, бутстрептест и расчет генетических дистанций Рейнольда) и Popgene version 1.32 (процент полиморфных локусов (P), генетическое разнообразие Нея (I), информационный индекс Шеннона (h), генетические дистанции Нея (D), показатель подразделенности популяций $\left.\left(\mathrm{G}_{\mathrm{st}}\right)\right)$.

\section{РЕЗУЛЬТАТЫ И ИХ ОБСУЖДЕНИЕ}

При оценке фитоценотической приуроченности выявлено, что ветреница енисейская в Восточном, Западном Саяне и в окр. г. Красноярска распространена в березовых, осиновых, сосновых и смешанных лесах, а также в поймах рек и на вырубках. Проективное покрытие A. jenisseensis в растительных сообществах варьирует от 1 до $10 \%$. Максимальное значение данный показатель имеет в западносаянском сосняке орляково-разнотравном (Aj1, 10\%). Также относительно высокие показатели численности ветреницы были зафиксированы в березово-сосновом лесу хвощоворазнотравном (Ај3, 5\%, Западный Саян). На вырубке сосняка со следами пожара $(\mathrm{Aj} 4 *)$ отмечено резкое снижение проективного покрытия особей вида до 1\%. В растительных сообществах вид выполняет роль ассектатора.

Среднее количество побегов ветреницы енисейской на 1 м $^{2}$ варьирует от 15 до 31 шт. Максимальная плотность $A$. jenisseensis зафиксирована для ЦП, произрастающей в окр. г. Красноярска (Ај9) $-30.7 \pm 5.7$ шт./м². В осиново-березовом ле-

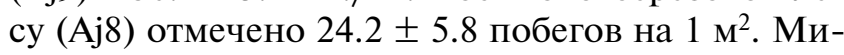
нимальное число побегов было выявлено на вырубке под ЛЭП (Аj10* $14.6 \pm 4.1$ шт./M²) и в березово-сосновом лесу орляково-разнотравнозлаковом в окр. с. Ермаковского, Западный Саян $\left(\right.$ Aj2, $15 \pm 2.5$ шт. $\left./ \mathrm{M}^{2}\right)$.

В результате изучения внутрипопуляционной изменчивости установлено, что большинство вегетативных признаков вида характеризуются средним и высоким уровнями изменчивости, согласно шкале С.А. Мамаева (Mamaev, 1972). Наименее изменчивыми признаками для побегов ветреницы являются длина стебля, длина цветоноса, длина черешка, длина центрального и бокового сегментов листа, форма центрального сегмента листа (рис. 2). Высокой степенью варьирования характеризуются степень и характер рассеченности центрального и боковых сегментов листа - от 


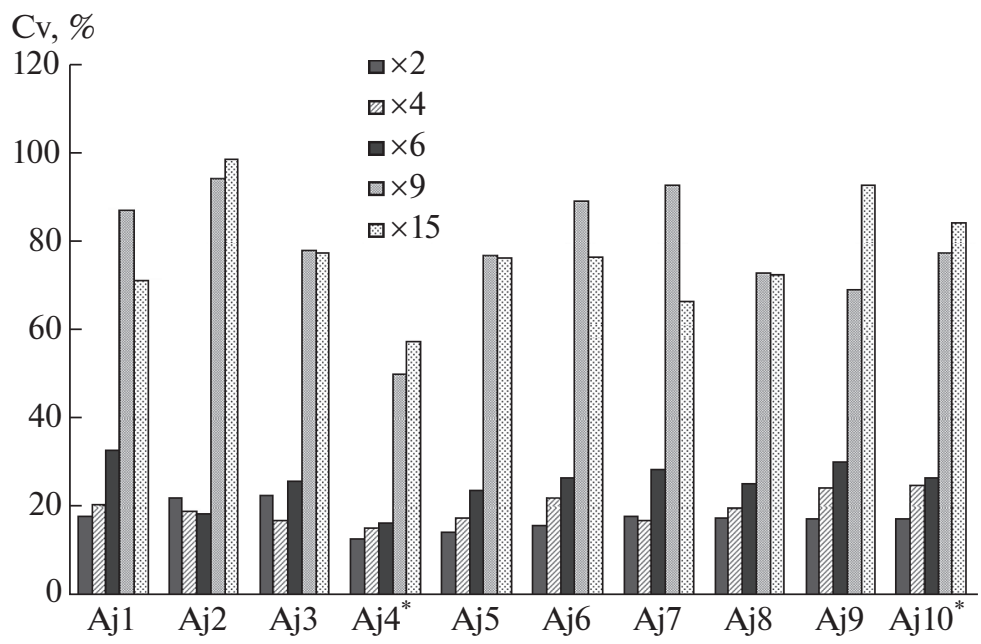

Рис. 2. Внутрипопуляционная изменчивость морфологических признаков Anemone jenisseensis: $\times 2$ - длина цветоноса, $\times 4$ - длина центрального сегмента листа, $\times 6$ - форма центрального сегмента листа, $\times 9$ - степень расчленения центрального сегмента, $\times 15$ - степень расчленения бокового сегмента.

Fig. 2. Intrapopulation variability of morphological characters of Anemone jenisseensis: $\times 2-$ peduncle length, $\times 4-$ central leaf segment length, $\times 6$ - central leaf segment shape, $\times 9-$ degree of incision of the central leaf segment, $\times 15-$ degree of incision of the lateral leaf segment.
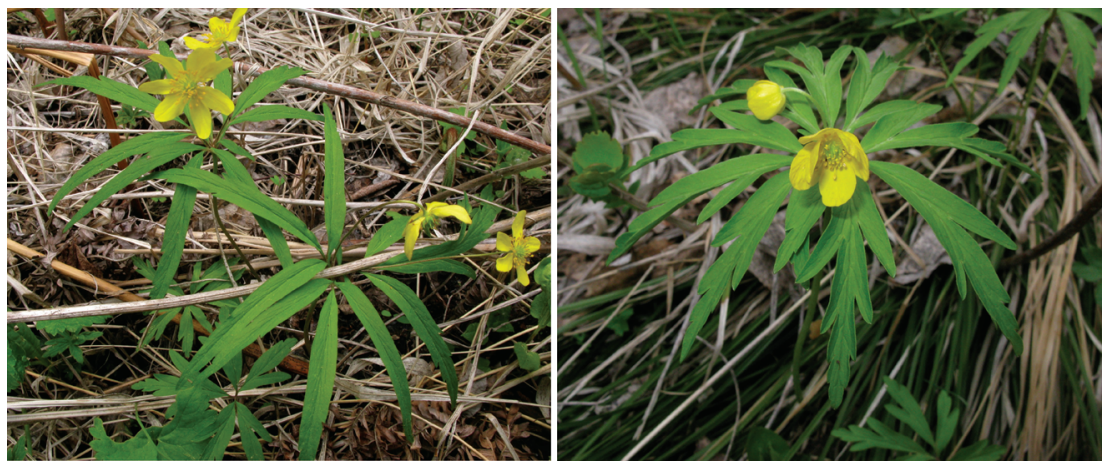

Рис. 3. Особи ветреницы енисейской с разной степенью расчленения листовых пластинок (фото Н.В. Степанова).

Fig. 3. Plants of Anemone jenisseensis with different degree of leaf blade incision (photo by N.V. Stepanov).

почти цельных до раздельных (рис. 3). Причем растения с разными типами расчленения листьев могут встречаться в пределах одной ценопопуляции. Три западносаянские ЦП (Aj1, Aj4* и Аj6) характеризуются глубоко расчлененными боковыми сегментами листьев.

Наибольшими размерами осевых органов (х1-х3) характеризуются особи, произрастающие в сосновых сообществах Западного Саяна (табл. 2): в сосняке орляково-разнотравном (Aj1), березовососновом лесу орляково-разнотравно-злаковом $(\mathrm{Aj} 2)$ и березово-сосновом лесу хвощово-разнотравном (Ај3). Например, длина стебля у особей ЦП Ај2 составляет 23.38 см, а длина цветоноса 5.49 см. Максимальные размеры листьев зафиксированы для западносаянских ЦП Ај3 и Аj5, а также для Ај9, находящейся в окр. г. Краснояр- ска. Минимальные показатели всех вегетативных признаков характерны для растений ветреницы енисейской, произрастающих на вырубке под ЛЭП (Ај10*) (табл. 2).

Высокие показатели реальной семенной продуктивности $A$. jenisseensis отмечены для ЦП Ај5 (пойменный ивняк широкотравно-страусниковый, Западный Саян), где количество завязавшихся плодов составляет 27.4 шт., а коэффициент семенификации равен $74.6 \%$ (табл. 3). Для ЦП Аj10*, произрастающей на вырубке под ЛЭП, сравнительно низкие значения морфологических параметров сочетаются с относительно высокими показателями семенной продуктивности, численности и средним уровнем внутрипопуляционной изменчивости, что свидетельствует о длительно действующих однотипных стрессовых 


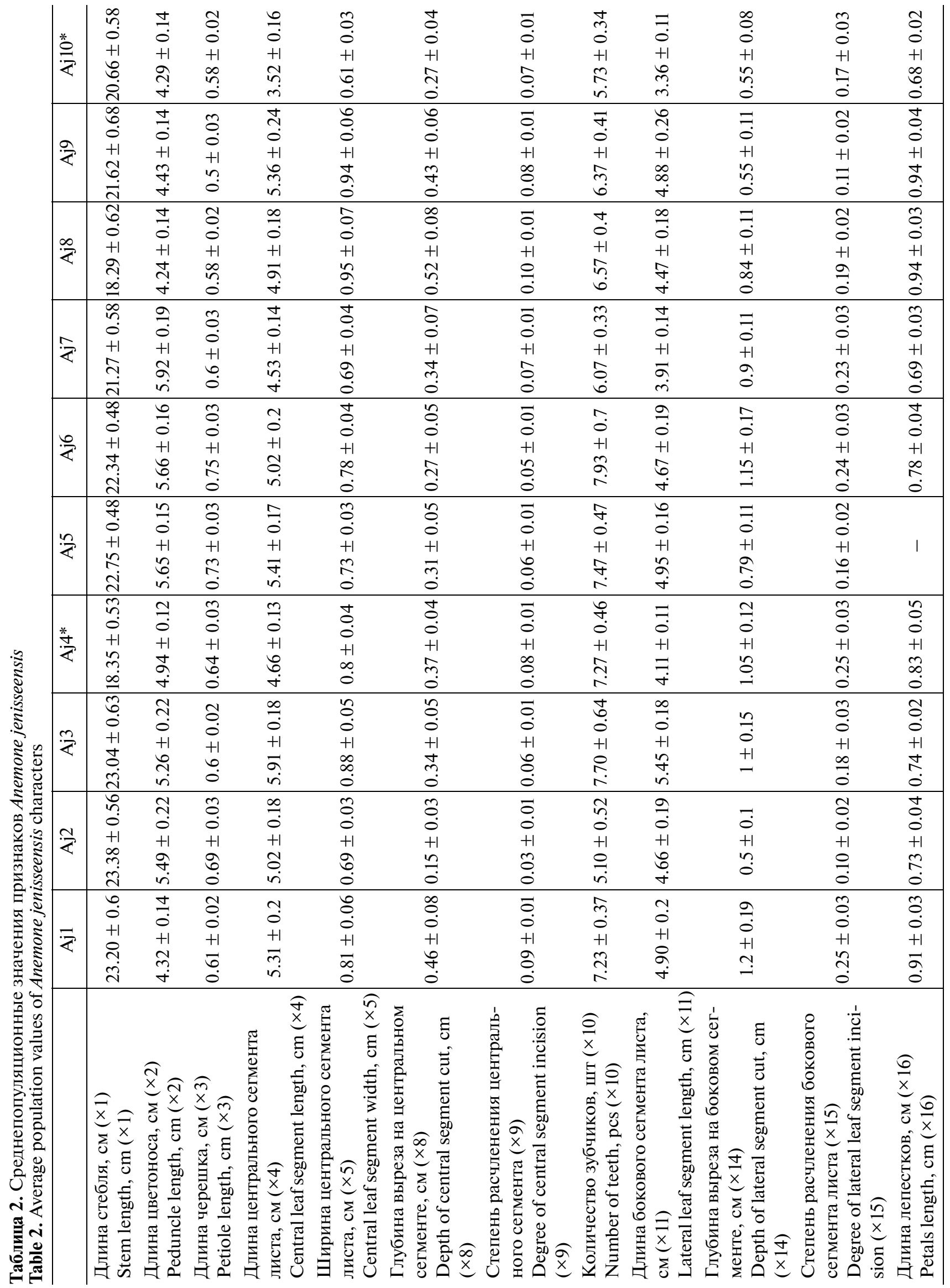


Таблица 3. Среднепопуляционные значения показателей семенной продуктивности Anemone jenisseensis Table 3. Average population values of seed productivity of Anemone jenisseensis

\begin{tabular}{c|c|c|c}
\hline $\begin{array}{c}\text { № ц/п } \\
\begin{array}{c}\text { Coenopopula- } \\
\text { tion number }\end{array}\end{array}$ & $\begin{array}{c}\text { Реальная семенная } \\
\text { продуктивность } \\
\text { Actual seed productivity }\end{array}$ & $\begin{array}{c}\text { Потенциальная семенная } \\
\text { продуктивность } \\
\text { Potential seed productivity }\end{array}$ & $\begin{array}{c}\text { Коэффициент } \\
\text { семенификации } \\
\text { Seed productivity coefficient }\end{array}$ \\
\hline Aj1 & $10.40 \pm 3.52$ & $26.47 \pm 2.30$ & $39.88 \pm 14.06$ \\
Aj2 & $17.30 \pm 1.57$ & $28.37 \pm 2.42$ & $66.46 \pm 4.09$ \\
Aj3 & 0 & $20.79 \pm 2.12$ & 0 \\
Aj4* & $17.36 \pm 2.40$ & $27.70 \pm 2.07$ & $56.84 \pm 4.18$ \\
Aj5 & $27.43 \pm 2.13$ & $37.73 \pm 2.56$ & $74.60 \pm 3.53$ \\
Aj6 & $14.54 \pm 1.77$ & $18.90 \pm 1.55$ & $64.91 \pm 5.22$ \\
Aj7 & $16.45 \pm 1.99$ & $23.83 \pm 2.24$ & $68.79 \pm 4.71$ \\
Aj8 & $17.60 \pm 3.36$ & $26.70 \pm 2.42$ & $47.37 \pm 7.98$ \\
Aj9 & $14.69 \pm 3.07$ & $25.34 \pm 2.51$ & $47.02 \pm 6.83$ \\
Aj10* & $17.38 \pm 1.78$ & $27.17 \pm 2.46$ & $61.47 \pm 4.90$ \\
\hline
\end{tabular}

Таблица 4. Полиморфизм межмикросателлитных фрагментов ДHK, амплифицированных ISSR-PCR методом Table 4. Polymorphism of intermicrosatellite DNA fragments amplified by ISSR-PCR method

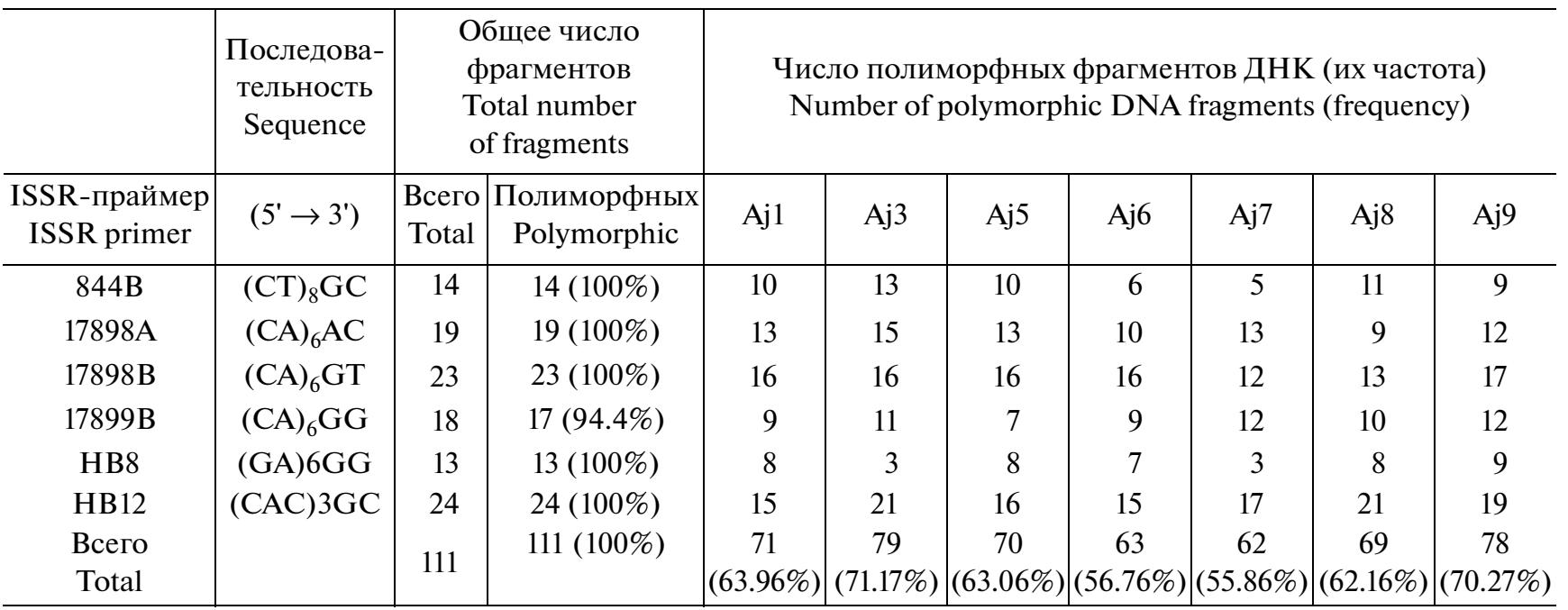

условиях (табл. 2, 3, рис. 2). Минимальные показатели семенной продуктивности (18.9 плодов на генеративный побег), отмечены для ЦП Ај6 (березово-сосновый лес папоротниково-широкотравный, Западный Саян).

На дендрограмме сходства, построенной с помощью кластерного анализа, наблюдается разделение совокупности ЦП на 2 кластера (рис. 4). В первый кластер объединились подтаежные западносаянские ЦП Ај7 и Аj2, а также примкнувшая к ним Aj10*, произрастающая на вырубке под ЛЭП. Для особей данных ЦП отмечаются небольшие размеры листьев и слабое расчленение боковых сегментов. Второй кластер формируют два подкластера. Первый объединяет красноярские ЦП Ај8 и Ај9 с относительно крупным центральным сегментом листа. Боковой сегмент средних размеров, слабо расчленен. Второй подкластер образуют западносаянские ЦП, особи которых характеризуются крупными размерами вегетативных органов. Внутри данного подкластера наблюдается разделение на две группы по размерам и степени расчленения бокового сегмента листа. Для особей группы ЦП Аj1, Aj4* и Аj6 отмечаются крупные и глубоко расчлененные боковые сегменты.

Генетический полиморфизм ветреницы енисейской изучен на примере ЦП, произрастающих в лесах Западного Саяна (Aj1, Аj3, Аj5-Аj7), Восточного Саяна (Ај8) и Красноярской лесостепи (Ај9). В ходе анализа выявлено 111 фрагментов ДНК. Суммарный процент полиморфизма составляет 100. Число амплифицированных фраг- 
Евклидово расстояние

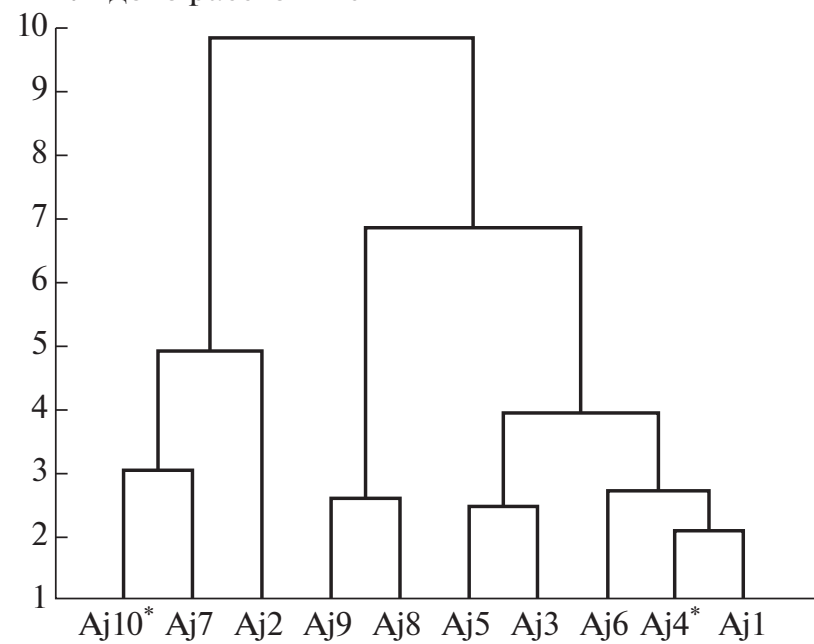

Рис. 4. Дендрограмма сходства ценопопуляций Anemone jenisseensis по морфологическим признакам. Ось Y Евклидово расстояние; ось $\mathrm{X}$ - ценопопуляции.

Fig. 4. Dendrogram of similarity of Anemone jenisseensis coenopopulations by morphological characters. Y-axis Euclidean distance; $\mathrm{X}$-axis - coenopopulations.

ментов ДНК, в зависимости от праймера (табл. 4), варьировало от 13 (НВ8) до 24 (НВ12).

Уровень выявляемого внутрипопуляционного генетического разнообразия средний (55.8671.17\%). Показатели генетического полиморфизма максимальны в западносаянской ЦП Ај3 (P = $=71.17 \% ; \mathrm{I}=0.275 ; \mathrm{h}=0.404)$ и красноярской $\mathrm{Aj} 9$ $(\mathrm{P}=70.27 \% ; \mathrm{I}=0.249 ; \mathrm{h}=0.373)$. Средними показателями генетического разнообразия характеризуются западносаянские ЦП Ај1 (P = 63.93\%; $\mathrm{I}=0.209 ; \mathrm{h}=0.32)$ и $\mathrm{Aj} 5(\mathrm{P}=63.06 \% ; \mathrm{I}=0.204 ; \mathrm{h}=$ $0.313)$. Минимальные значения отмечены для $\mathrm{Aj} 7$ $(\mathrm{P}=55.86 \% ; \mathrm{I}=0.189, \mathrm{~h}=0.287)$.

Коэффициент подразделенности ЦП $\left(\mathrm{G}_{\mathrm{st}}\right)$ coставляет 0.3316. Следовательно, на долю межпопуляционного разнообразия приходится $33.16 \%$, а изученные ЦП ветреницы демонстрируют очень высокую степень дифференциации (Wright, 1978). Генетические дистанции М. Нея

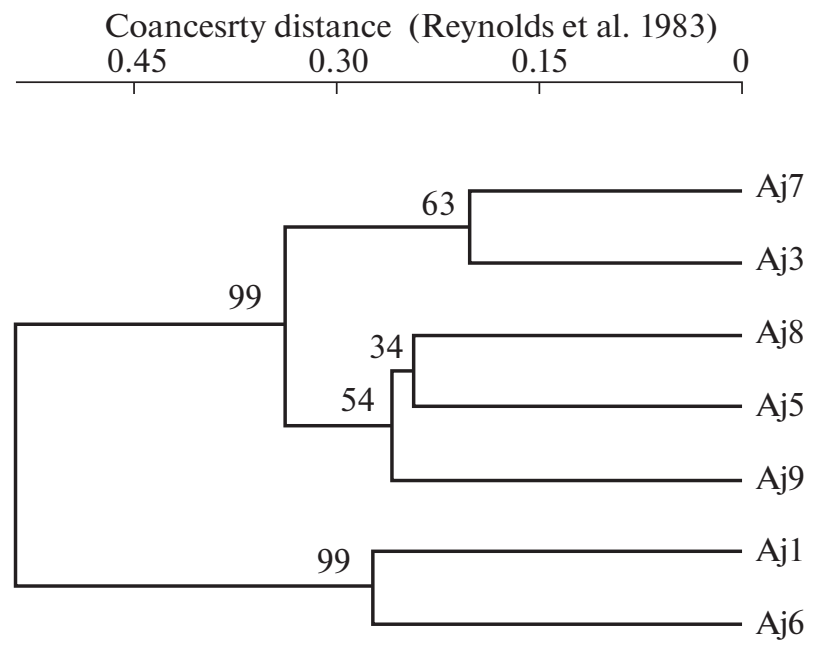

Рис. 5. Дендрограмма сходства ценопопуляций Anemone jenisseensis на основе данных ISSR-PCR анализа (цифрами указаны значения бутстрепа в \%).

Fig. 5. Dendrogram of similarity of Anemone jenisseensis coenopopulations based on ISSR-PCR analysis data (the numbers indicate bootstrap values, \%).

(Nei, 1972) минимальны между западносаянскими $A j 7$ и Aj3 $(D=0.0892)$. Максимальные расстояния зафиксированы между ЦП Aj6 и Aj7 (D = $=0.2788)$ (табл. 5).

Ha UPGMA-дендрограмме сходства ЦП с высокой степенью достоверности выделяются два кластера (рис. 5). Первый кластер делится на два подкластера. В первый входят подтаежные западносаянские ЦП Ај3 и Ај7, во второй - красноярские Аj8 и Ај9 и западносаянская Аj5. Второй кластер образуют популяции Aj1 и Aj6, произрастающие в сосняках Западного Саяна и характеризующиеся крупными рассеченными боковыми долями листа. Данные ЦП отличались от других и по морфологическим признакам (рис. 4).

\section{ЗАКЛЮЧЕНИЕ}

Проведенный анализ состояния ЦП ветреницы енисейской показал, что изучаемый вид обладает относительно широким фитоценотическим

Таблица 5. Генетические дистанции Нея (1972) между ценопопуляциями Anemone jenisseensis на оcнове ISSR-PCR Table 5. Nei's genetic distances between Anemone jenisseensis coenopopulation based on ISSR-PCR

\begin{tabular}{c|c|c|c|c|c|c}
\hline $\begin{array}{c}\text { № ц/п } \\
\text { Coenopopulation number }\end{array}$ & Aj1 & Aj3 & Aj5 & Aj6 & Аj7 & Aj8 \\
\hline Aj3 & 0.2269 & & & & & \\
Aj5 & 0.2024 & 0.1026 & & & & \\
Aj6 & 0.1068 & 0.2390 & 0.2397 & & & \\
Aj7 & 0.2499 & 0.0892 & 0.1452 & 0.2788 & & \\
Aj8 & 0.2286 & 0.1154 & 0.0963 & 0.2494 & 0.1742 & \\
Аj9 & 0.2113 & 0.1747 & 0.1184 & 0.2630 & 0.1901 & 0.1112 \\
\hline
\end{tabular}


ареалом и может встречаться в мелколиственных (березовые, осиновые леса), светлохвойных (сосняки), смешанных лесах, в пойменных ивняках, а также на вырубках.

Максимальные размеры вегетативных органов, показатели семенной продуктивности, генетического разнообразия зафиксированы для ЦП A. jenisseensis, произрастающих в лесах Западного Саяна (Ај3, Ај5) и Красноярской лесостепи (Ај9). На вырубке под ЛЭП (Ај10*) низкие значения морфологических параметров сочетаются с относительно высокими показателями семенной продуктивности, численности и средним уровнем изменчивости, что свидетельствует о длительно действующих стрессовых условиях.

ЦП A. jenisseensis демонстрируют очень высокую степень генетической дифференциации $\left(\mathrm{G}_{\mathrm{st}}=0.3316\right)$. Важным диагностическим признаком, позволяющим разделить ЦП ветреницы енисейской, является степень расчленения сегментов листа. ЦП Аj1 и Ај6, характеризующиеся крупными расчлененными боковыми долями листа, формируют морфологически и генетически обособленную группу. Четкого разделения ценопопуляций по географическому принципу не выявлено.

\section{СПИСОК ЛИТЕРАТУРЫ}

[Barykina] Барыкина Р.П. 1995. Поливариантность способов естественного вегетативного размножения и расселения в семействе Ranunculaceae Бюлл. МОИП. Отд. биол. 100 (1): 53-64.

Cai Y., Li S.-W., LiuY., Quan S., Chen M., Xie Y.-F., Jiang H.-Z., Wei E.-Z., Yin N.-W., Wang L., Zhang R., Huang C.-L, He X.-H., Jiang M.-F. 2009. Molecular phylogeny of Ranunculaceae based on internal transcribed spacer sequences. - Afr. J. Biotechnol. 8 (20): 5215-5224.

[Dyuryagina, Ivanova] Дюрягина Г.П., Иванова М.M. 1985. Характеристика ценопопуляций редких видов флоры Бурятии. - Бот. журн. 70 (11): 1529-1538.

[Filippov, Andronova] Филиппов Е.Г., Андронова Е.В. 2017. Генетическая структура популяций и естественная гибридизация Dactylorhiza salina и D. incarnata (Orchidaceae). - Генетика. 53 (3): 310-323.

Jiang N., Zhou Z., Yang J.B., Zhang S.D., Guan K.Y., Tan Y.H., Yu W.B. 2017. Phylogenetic reassessment of tribe Anemoneae (Ranunculaceae): Non-monophyly of Anemone s.l. revealed by plastid datasets. - PLoS ONE. 12 (3): e0174792.

https://doi.org/10.1371/journal.pone.0174792

[Luferov, Starodubtsev] Луферов А.Н., Стародубцев В.Н. 1995 Семейство лютиковые (Ranunculaceae). В кн.: Сосудистые растения Советского Дальнего Востока. Т. 7. СПб. С. 9-145.

[Mamaev] Мамаев С.А. 1972. Формы внутривидовой изменчивости древесных растений. М. 284 с.

[Marinicheva, Yamskikh] Мариничева А.Н., Ямских И.Е. 2017. Полиморфизм популяций Anemone reflexa (Ranunculaceae) в горах Южной Сибири. - Вестник КрасГАУ. 7 (130): 126-133.
Mansour A., Ismail H.M., Ramadan M.F., Gyulai G. 2009. Variations in tomato (Lycopersicon esculentum) cultivars grown under heat stress. - Journal fur verbrauchersschutz und lebensmittelsicherheit. 1.4: 118-127.

Miller M.P. 1997. Tools for population genetic analyses (TFPGA) 1.3: A Windows program for the analysis of allozyme and molecular population genetic data.

Mlinarec J., Satovic Z., Malenica N., Ivancic-Bace I., Besendorfer V. 2012. Evolution of the tetraploid Anemone multifidi $(2 \mathrm{n}=32)$ and hexaploid $A$. baldensis $(2 \mathrm{n}=$ 48) (Ranunculaceae) was accompanied by rDNA loci loss and intergenomic translocation: evidence for their common genome origin. - Ann. Bot. 110 (3): 703-712. https://doi.org/10.1093/aob/mcs128

Nei M. 1972. Genetic Distance between Populations. Am. Nat. 106: 283-292.

Paterson I.D., Downie D.A., Hill M.P. 2009. Using molecular methods to determine the origin of weed populations of Pereskia aculeata in South Africa and its relevance to biological control. - Biol. Control. 1.48: 8491.

[Popov] Попов М.Г. 1957. Семейство лютиковые (Ranunculaceae). - В кн.: Флора Средней Сибири. Т. 1. М., Л. С. $250-274$.

[Red...] Красная книга Иркутской области. 2010. Иркутск. 478 с.

[Schmidt] Шмидт В.M. 1984. Математические методы в ботанике. - Л. 288 с.

Schuettpelz E., Hoot. S.B., Samuel R., Ehrendorfer F. 2001. Multiple origins of Southern Hemosphere Anemone (Ranunculaceae) based on plastid and nuclear sequence data. - Plant Syst. Evol. 231: 143-151.

Sun M., Yin X., Shi F., Li L., Li M., Li L., Xiao H. 2012. Development of Eighteen Microsatellite Markers in Anemone amurensis (Ranunculaceae) and Cross-Amplification in Congeneric Species. - Int. J. Mol. Sci. 13: 4889-4895. https://doi.org/10.3390/ijms13044889

[Timokhina] Тимохина С.А. 1993. Семейство лютиковые (Ranunculaceae). - В кн.: Флора Сибири. Т. 6. Новосибирск. С. 145-149.

[Voronov] Воронов А.Г. 1973. Геоботаника. 384 с.

Ward J.H.Jr. 1963. Hierarchical Grouping to Optimize an Objective Function. - Journal of the American Statistical Association. 58: 236-244.

Wright S. 1978. Evolution and the Genetics of Populations: Variability within and among natural populations. University of Chicago Press. 4: 590.

[Yamskikh et al.] Ямских И.Е., Куцев М.Г., Уварова О.В. 2011. Полиморфизм популяций Anemonoides altaica (C.A. Mey.) Holub в горах Южной Сибири на основе морфологических данных и ISSR-PCR анализа. Turczaninowia. 14 (1): 8-16.

[Yuzepchuk] Юзепчук С.В. 1937. Семейство лютиковые (Ranunculaceae). - В кн.: Флора СССР. Т. 7. М., Л. C. 225-282.

Zhang Y., Hong Y., Ren C., Ming T., Hoot S.B., Yang Q.E. 2015. Palynology, cytology, and molecular systematics of Anemone section Begoniifolia (Ranunculaceae). Plant Syst. Evol. 301 (1): 411-424.

https://doi.org/10.1007/s00606-014-1082-0 


\title{
MORPHOLOGICAL AND GENETIC VARIABILITY OF ANEMONE JENISSEENSIS (RANUNCULACEAE) COENOPOPULATIONS IN THE SOUTHERN YENISEI AREA (SIBERIA)
}

\author{
A. N. Marinicheva ${ }^{a, \#}$, I. E. Yamskikh ${ }^{a}$, N. V. Stepanov ${ }^{a}$, and M. G. Kutsev ${ }^{a, b}$ \\ a Siberian Federal University \\ Svobodnyy Ave., 79, Krasnoyarsk, 660041, Russia \\ ${ }^{b}$ Altai State University \\ Lenina Ave., 61, Barnaul, 656049, Russia \\ \# e-mail: alexandra.marinicheva@outlook.com
}

\begin{abstract}
The genetic variability and phenotypic plasticity of 10 natural coenopopulations of the Siberian endemic Anemone jenisseensis (Korsh.) Krylov, which grows in plant communities of the Krasnoyarsk forest-steppe, Western and Eastern Sayan, were studied. The species has been established to have a relatively wide phytocenotic range and occurs in small-leaved forests (birch, aspen forests), light coniferous (pine) forests, mixed forests, in floodplain willow standss, and on cuttings. The average number of shoots per $1 \mathrm{~m}^{2}$ varies from 15 to 31. The maximum sizes of vegetative organs, indices of seed productivity and genetic diversity of the species were observed in the subtaiga forests of the Western Sayan and in the Krasnoyarsk forest-steppe. A significant decrease in the morphological characters of $A$. jenisseensis was noted in the cutted areas; the level of intrapopulation phenotypic plasticity and seed productivity indices, however, vary within the average values.

The genetic variability of the $A$. jenisseensis coenopopulations was studied using the ISSR-PCR (Inter Simple Sequence Repeats) method. The total percentage of polymorphic loci is 100 . The studied coenopopulations are characterized by the average level of intrapopulation genetic diversity (55.86-71.17\%) and a very high degree of differentiation $(\mathrm{Gst}=0.3316)$. The similarity dendrograms based on morphological and genetic data reliably distinguish a group of coenopopulations characterized by large, deeply divided lateral segments of leaves. Geographical separation of the coenopopulations was not identified.
\end{abstract}

Keywords: Anemone jenisseensis, endemic species, morphological and genetic analyses, coenopopulations, ISSR-PCR, genetic diversity, Southern Siberia, Krasnoyarsk Territory, Khakassia

\section{REFERENCES}

Barykina R.P. 1995. Polivariantnost sposobov yestestvennogo vegetativnogo razmnozheniya i rasseleniya $\mathrm{v}$ semeystve Ranunculaceae [Polyvariance of methods of natural vegetative propagation and settlement in the Ranunculaceae family]. - Bull. MOIP. Otd. biol. 100 (1) : 53-64 (In Russ.).

Cai Y., Li S.-W., Liu Y., Quan S., Chen M., Xie Y.-F., Jiang H.-Z., Wei E.-Z., Yin N.-W., Wang L., Zhang R., Huang C.-L., He X.-H., Jiang M.-F. 2009. Molecular phylogeny of Ranunculaceae based on internal transcribed spacer sequences. - Afr. J. Biotechnol. 8 (20): 5215-5224.

Dyuryagina G.P., Ivanova. M.M. 1985. Kharakteristika tsenopopulyatsii redkikh vidov flory Buryatii [Characteristics of coenopopulations of rare species in the Buryatian flora]. - Botanicheskii zhurnal. 70 (11): 1529-1538 (In Russ.).

Filippov E.G., Andronova E.V. 2017. Genetic structure of populations and natural hybridization between Dactylorhiza salina and D. incarnata (Orchidaceae). - Russian Journal of Genetics. 53 (3): 325-337.

Jiang N., Zhou Z., Yang J.B., Zhang S.D., Guan K.Y., Tan Y.H., Yu W.B. 2017. Phylogenetic reassessment of tribe Anemoneae (Ranunculaceae): Non-monophyly of Anemone s.l. revealed by plastid datasets. - PLoS ONE. 12 (3): e0174792.

https://doi.org/10.1371/journal.pone.0174792.
Luferov A.N., Starodubtsev V.N. 1995. Semeystvo lyutikovyye (Ranunculaceae) [Ranunculaceae Juss.]. - In: Vascular plants of the Soviet Far East. Vol. 7. St. Petersburg. P. 9-145 (In Russ.).

Mamaev S.A. 1972. Formy vnutrividovoy izmenchivosti drevesnykh rasteniy [Forms of intraspecific variability of woody plants]. Moscow. 284 p. (In Russ.).

Mansour A., Ismail H.M., Ramadan M.F., Gyulai G. 2009. Variations in tomato (Lycopersicon esculentum) cultivars grown under heat stress. - Journal fur verbrauchersschutz und lebensmittelsicherheit. 1.4: 118-127.

Marinicheva A.N., Yamskikh I.E. 2017. Polimorfizm populyacij Anemone reflexa (Ranunculaceae) v gorah Yuzhnoj Sibiri [Polymorphism of Anemone reflexa (Ranunculaceae) populations in the mountains of Southern Siberia]. - Vestnik KrasGAU. 7 (130): 126133 (In Russ.).

Miller M.P. 1997. Tools for population genetic analyses (TFPGA) 1.3: A Windows program for the analysis of allozyme and molecular population genetic data.

Mlinarec J., Satovic Z., Malenica N., Ivancic-Bace I., Besendorfer V. 2012. Evolution of the tetraploid Anemone multifida $(2 \mathrm{n}=32)$ and hexaploid $A$. baldensis $(2 \mathrm{n}=48)$ (Ranunculaceae) was accompanied by rDNA loci loss and intergenomic translocation: evidence for their common genome origin. - Ann. Bot. 110 (3): 703-712. https://doi.org/10.1093/aob/mcs128

Nei M. 1972. Genetic Distance between Populations. Am. Nat. 106: 283-292. 
Paterson I.D., Downie D.A., Hill M.P. 2009. Using molecular methods to determine the origin of weed populations of Pereskia aculeata in South Africa and its relevance to biological control. - Biol. Control. 1.48: 8491.

Popov M.G. 1957. Semeystvo lyutikovyye (Ranunculaceae) [Ranunculaceae Juss.]. - In: Flora srednei Sibiri [Flora of Central Siberia] T. 1. Moscow; Leningrad. P. 250274 (In Russ.).

Red data book of nature of the Irkutsk region. 2010. Irkutsk. 478 p. (In Russ.).

Schmidt V.M. 1984. Matematicheskiye metody v botanike [Mathematical Methods in Botany]. Leningrad. 288 p. (In Russ.).

Schuettpelz E., Hoot. S.B., Samuel R., Ehrendorfer F. 2001. Multiple origins of Southern Hemosphere Anemone (Ranunculaceae) based on plastid and nuclear sequence data. - Plant Syst. Evol. 231: 143-151.

Sun M., Yin X., Shi F., Li L., Li M., Li L., Xiao H.2012. Development of Eighteen Microsatellite Markers in Anemone amurensis (Ranunculaceae) and Cross-Amplification in Congeneric Species. - Int. J. Mol. Sci. 13: 4889-4895. https://doi.org/10.3390/ijms13044889
Timokhina S.A. 1993. Semeystvo lyutikovyye (Ranunculaceae) [Ranunculaceae Juss.]. - In: Flora of Siberia. T.6. Novosibirsk. P. 145-149 (In Russ.).

Voronov A.G. 1973. Geobotanika [Geobotany]. 384 p. (In Russ.).

Ward J.H.Jr. 1963. Hierarchical Grouping to Optimize an Objective Function. - Journal of the American Statistical Association. 58: 236-244.

Wright S. 1978. Evolution and the Genetics of Populations: Variability within and among natural populations. University of Chicago Press. 4: 590.

Yamskikh I.E., Kutsev M.G., Uvarova O.V. 2011. Polymorphism of Anemonoides altaica (C.A. Mey.) Holub Populations in the South Siberia Mountains based on morphological data and ISSR-PCR analysis. Turczaninowia. 14 (1): 8-16 (In Russ.).

Yuzepchuk S.V. 1937. Semeystvo lyutikovyye (Ranunculaceae) [Ranunculaceae Juss.]. - In: Flora SSSR. T.7. Moscow, Leningrad. P. 225-282 (In Russ.).

Zhang Y., Hong Y., Ren C., Ming T., Hoot S.B., Yang Q.E. 2015. Palynology, cytology, and molecular systematics of Anemone section Begoniifolia (Ranunculaceae). Plant Syst. Evol. 301 (1): 411-424.

https://doi.org/10.1007/s00606-014-1082-0 